\title{
Status and challenges of integrated watershed management practices after-project phased-out in Eastern Tigray, Ethiopia
}

\author{
Tirhas Gebregergs $^{1} \cdot$ Kassa Teka $^{1} \cdot$ Gebeyehu Taye $^{1} \cdot$ Eskinder Gidey $^{1} \cdot$ Oagile Dikinya ${ }^{2}$
}

Received: 5 October 2020 / Accepted: 5 January 2021 / Published online: 4 April 2021

(c) The Author(s) 2021

\begin{abstract}
Land degradation in the form of soil erosion is one of the major causes for declining ecosystem functions in the northern highlands of Ethiopia including the Eastern Tigray. Hence, different integrated watershed management practices were introduced in the last few years to avert the problem. Currently, most of these practices are phased out. However, the status and challenges of these practices after phase-out are not well documented and required scientific research. On-field measurement from nine sample plots having a size of each $50 \mathrm{~m} * 50 \mathrm{~m}$ at $200 \mathrm{~m}$ interval was conducted to assess the status and challenges of these practices. Results of the assessment showed that physical soil and water conservation structures were deteriorated by $47-64 \%$ after IWM project phased out. The key problems were lack of periodic maintenance, and limited support by biological conservation measures. The study results suggest that Watershed technologies are highly challenged after project phase-out. Hence, integration among the community, government and non-governmental organizations are needed to sustainably manage these resources.
\end{abstract}

Keywords Watershed $\cdot$ Soil and water conservation challenges $\cdot$ Tigray

\section{Introduction}

Land degradation in the form of soil erosion, sedimentation, water pollution, soil nutrient depletion, deforestation and overgrazing is the major cause for poor land productivity (Bekele 2003; Berry 2003; Arabia et al. 2013; Temesgen et al. 2013; Balasubramani et al. 2015). Several studies reported that soil erosion in the Ethiopian highlands ranged from $42 \mathrm{tha}^{-1} \mathrm{y}^{-1}$ on arable land to $179 \mathrm{tha}^{-1} \mathrm{y}^{-1}$ on range lands (Hurni 1993; Shiferaw and Holden 1999). More than 50 percent of Ethiopia's highlands were substantially eroded (FAO 1986), which led to reduced land productivity by 2.2 percent annually (Tamene et al. 2006). On the other hand, the total land area deteriorated in the country, between 1981

Tirhas Gebregergs

tirhas.gebregergs@mu.edu.et

1 Department of Land Resources Management and Environmental Protection (LaRMEP), College of Dryland Agriculture and Natural Resources, Mekelle University, Mekelle, Ethiopia

2 Department of Environmental Science, Faculty of Science, University of Botswana, Private bag 00704, Gaborone, Botswana and 2003, was $297,000 \mathrm{~km}^{2}$ (FAO 2006). Land degradation accompanied by population pressure and climate variability constrained agricultural productivity (Deressa and Hassan 2009; Teka et al. 2014). This, in turn, resulted to severe consequences, such as food insecurity and environmental hazards, such as chronic drought and poverty (Tekle 1999). To avert these challenges, since the 1970s and 1980s, many land restoration initiatives, such as soil and water conservation measures, have been implemented with a financial support from the international community, particularly the World Food Program (MoARD 2005; Zeleke et al. 2006; Nyssen et al. 2007; Gashaw 2015). However, due to the top-down approaches followed (no to low community participation), limited number of watershed practices (poor integration) and large/unmanageable watersheds (for monitoring and management), most of the implemented measures failed (Temesgen et al. 2013).

These challenges call for a societal shift towards a sustainable development model, which encompasses community participation, and objectives integration (CCME 2016; Teka 2019). Hence, the Ethiopian government in collaboration with partners (Irish development co-operation programme, Irish Aid) has implemented a range of integrated watershed management practices, such as soil and water 
conservation (both physical and biological) and exclosures to keep land free from human and livestock interference in Tigray since 1997 (Bekele and Tilahun 2007; Chisholm and Woldehanna 2012). Integrated watershed management is a method of continuous restoration, growth and efficient use of available natural resources in a watershed, and a multidisciplinary approach to soil depletion pause (Mekonen and Fekadu 2015; Karpuzcu and Delipinar 2011). Hence, until 2014, the total area delineated and treated with integrated watershed management activities in the region was 12,425,869 hectares (BoARD 2016).

Studies showed that the implemented integrated watershed interventions increased infiltration and decreased runoff production (Nyssen et al. 2007; Taye et al. 2013); improved soil fertility (Vancampenhout et al. 2006; Nyssen et al. 2007); improved vegetation regeneration and soil build-ups (Mekuria et al. 2007); improved soil fertility (Vancampenhout et al. 2006; Nyssen et al. 2007); improved vegetation regeneration and soil build-ups (Mekuria et al. 2007; Etsay et al. 2019); improved groundwater (Nyssen et al. 2010). However, most of the watersheds are phased out about five years after implementation. Phase-out refers to the withdrawal of project inputs without continuity of support or arrangements of watershed management practices of the government and non-governmental organizations (Zeleke 2014). Nevertheless, none of the above and other studies dealt on the status and challenges of the implemented watershed interventions after Watershed project phased out. Hence, this study aimed at providing information on the status and challenges of watershed management activities after their phased-out so as to support planners, researchers and practitioners in sustaining project development intervention.

\section{Materials and methods}

\section{Study area}

The study was conducted in six watersheds (Adikesho, Deberewahabit, Gemad, Debretsion, Laelay wukro and Tsigerda) located in the Kilte Awlaelo district of Eastern Tigray, Ethiopia (Fig. 1). These watersheds represent the midland areas (1500-2300 m.a.s.l) of the Tigray region, which occupy $86.9 \%$ of the land mass. Geographically, the study district is located at $13^{\circ} 33^{\prime} 00^{\prime \prime}$ and $13^{\circ} 58^{\prime} 00^{\prime \prime}$ North and $39^{\circ} 18^{\prime} 00^{\prime \prime}$ to $39^{\circ} 41^{\prime} 00^{\prime \prime}$ East at an elevation between 1760 and 2720 m.a.s.l.

The total land mass of the district is 101,758 ha comprising farmlands (21,620 hectare), grazing lands ( $7,930.85 \mathrm{ha})$, exclosures (44,134 ha) and unproductive hills and residential areas (28,073.15 ha) (MoARD 2007). The kilte-Awulaelo

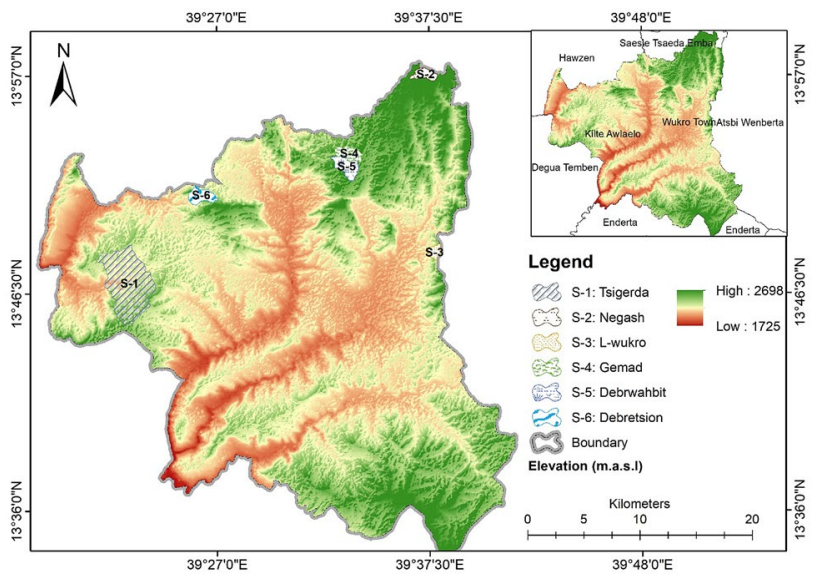

Fig. 1 Location map of the study area

district is characterized by Degua/cool, humid highland zone (13.1\% of the land mass) which is located at an altitudes of above $2300 \mathrm{~m}$ above mean sea level, and midland/ Weina-Douga ( $86.9 \%$ of the land mass), which is located at an altitude that ranges between 1500 and $2300 \mathrm{~m}$ above mean sea level (Rabia et al. 2013). The mean annual rainfall ranges from 500 to $1200 \mathrm{~mm}$. Maximum temperature $\left(34{ }^{\circ} \mathrm{C}\right)$ ) was observed in May and June; while minimum temperature $\left(16^{\circ} \mathrm{C}\right)$ was observed between September and December. The study area is dominated by igneous and metamorphic rocks (Precambrian, Paleozoic) (Rabia et al. 2013). The main reference soil groups are classified as Leptosols (36.8\%), Calcisols (15.84\%), Vertisols (14.64\%), Cambisols (9.01\%), Regosols (5.83\%), Arenosols (5.72\%), Phaeozems (5.13\%), Luvisols (3.44\%), Fluvisols (2.17\%), Kastanozems (1.26\%) and Stagnosols (0.16\%) (Rabia et al. 2013). Community's livelihood mainly depends on agriculture, which is characterized as mixed farming in which crops are produced and livestock reared, and managed on the same farm. The major crops grown are barley (Hordeum vulgare), wheat (Triticum sativum), teff (Eragrostis teff) and millet (Eleusine coracana). While, the major livestock herds are sheep, camel, mule, bees, donkeys, cattle, chicken and goats.

\section{Methods of data collection}

\section{Site selection}

The studied watersheds were deliberately selected for having an age of seven years after the watershed project phased out, and representing the midland agro-ecology. The selection of these six watersheds was carried out in consultation with Watershed experts and district administrator. The selection considered three successful and three unsuccessful watersheds 
following the criteria set by the Tigray Bureau of Agriculture and Rural Development. The Bureau put three major categories to classify watersheds into successful and unsuccessful (threshold $>50 \%$ ): (i) Ecological (vegetation cover, ground water recharge, flood reduction, surface run-off reduction and animal diversity); (ii) socio-economic (irrigation water availability, women participation, and fodder production); (iii) Status of implemented soil and water conservation measures (biological and physical).

\section{On-field measurement}

In each Watershed, 3 transect lines were laid along the slope to determine the status of soil and water management systems and their challenges. For sampling purposes, each Watershed was divided into three parts according to the FAO (2006): upper slope ( $>25$ percent), middle slope (15-25 percent) and lower slope $(<15$ percent). Nine (9) sample plots having a size of $50 \mathrm{~m} * 50 \mathrm{~m}$ were laid within each transect at a $200 \mathrm{~m}$ distance as suggested in (Demissie and Fisseha 2016).

\section{Social survey}

Additional information on the status and challenges of watershed management activities after phased-out watershed projects was obtained from household watershed beneficiaries' interview and focus group discussions. The sample size was determined by the following equation proposed in Glenn (1992). Interviewees were selected from the identified three locations (upper user, middle user and lower user) following a systematic random sampling method.

$n=\frac{N}{1+\mathrm{N}(\mathrm{e}) 2}$

where $n=$ sample size; $\mathrm{N}=$ household size of the population; $\mathrm{e}=$ acceptable sampling error $(10 \%)$.

\section{Data analysis}

Data were initially tested for normality. The numbers of physical soil and water conservation measures lost and damaged in each watershed were not usually normally distributed. Hence, no normality was changed to $\log 1$, using SPSS version 20 statistical software. The lost or impaired physical soil and water protection measures were compared against the successful and unsuccessful measures using an independent two sample $t$ test. Descriptive statistics were also used to examine the major problems facing integrated watershed management activities at the watershed and the major physical soil and water conservation measures.

\section{Results}

\section{Implemented IWM practices}

Several physical conservation measures with the purpose of reducing surface runoff and increasing infiltration were implemented through governmental and non-governmental organizations in the study watersheds. The major physical IWM structures constricted on the upper, middle and lower slope of the study watersheds include hillside terrace, terraces, stone bund, shallow trench, deep trench, half-moon, percolation pond, gabion check dams, lose stone check dam and hand dug well (Tables 1 and 2).

\section{Status of the implemented IWM practices}

The results indicated that broken shallow trench with stone band structure in the upper slope was statistically different $(P<0.022)$ between the successful and unsuccessful watersheds. About 64 percent and 47 percent of the IWM physical measures were damaged in both unsuccessful and successful watershed, respectively (Table 3). The demolished hillside terrace and stone band note significant variations between $P<0.005$ and $P<0.004$ (57.2 percent and 70.5 percent), respectively, on the active watershed.

The ruined IWM physical measures on the middle slope showed a significant difference $(P<0.05)$ between the successful and unsuccessful watersheds (Table 4 ). The ruined hillside terrace on the middle slope of unsuccessful was by 14.4 percent higher than that on the successful watershed. Similarly, the ruined half-moon structure was slightly higher (by 19 percent) on the unsuccessful watershed than that on the successful watershed. On the other side, stone bund destruction on unsuccessful watersheds was by 14.3 percent higher than that on the successful one.

The IWM measures on the lower slope had a significant different between Watersheds (Table 5). The lost gabion check dam on the lower slope of the unsuccessful watersheds was by 47.8 percent higher than that on the unsuccessful one. Similarly, broken deep trench with stone bund, loose

Table 1 Number of beneficiaries and sample size in each Watershed

\begin{tabular}{lll}
\hline Watershed name & Number of beneficiaries & Sample size \\
\hline Adikesho & 300 & 57 \\
Debrwahbit & 300 & 75 \\
Gemad & 255 & 71 \\
Debretsion & 350 & 77 \\
Laelay wukro & 120 & 54 \\
Tsigerda & 300 & 75 \\
Total & 1625 & 409 \\
\hline
\end{tabular}


Table 2 Soil and water conservation practices in six watersheds

\begin{tabular}{|c|c|c|c|c|c|c|}
\hline Name-w & U-slope & $\begin{array}{l}\text { No of struc- } \\
\text { tures }\end{array}$ & MI-slope & $\begin{array}{l}\text { No of struc- } \\
\text { tures }\end{array}$ & L-slope & $\begin{array}{l}\text { No of } \\
\text { struc- } \\
\text { tures }\end{array}$ \\
\hline \multirow[t]{3}{*}{ Adikesho } & Hillside terrace & 35 & Half-moon & 37 & Gabion check dam & 25 \\
\hline & Terraces & 65 & Stone bund & 68 & Loss stone check dam & 18 \\
\hline & Stone bund & 15 & Stone bund & 14 & Percolation pond & 4 \\
\hline \multirow[t]{4}{*}{ Debrewahabit } & Shallow trench & 98 & Hillside terrace & 103 & Deep trench & 31 \\
\hline & Hillside terrace & 41 & Deep trench & 79 & Gabion check dam & 40 \\
\hline & Stone bund & 60 & Shallow trench & 39 & Pond & 9 \\
\hline & & & Half-moon & 35 & Lose stone check dam & 25 \\
\hline \multirow[t]{4}{*}{ Gemad } & Shallow trench & 55 & Half-moon & 37 & Gabion check dams & 9 \\
\hline & Deep trench & 27 & Hillside terrace & 23 & Lose stone check dams & 32 \\
\hline & Stone bund & 50 & Shallow trench & 49 & Percolation pond & 4 \\
\hline & & & Deep trench stone bund & 22 & Hand dug well & 18 \\
\hline \multirow[t]{3}{*}{ Debretsion } & Hillside terrace & 65 & Half moon & 180 & Gabion check dam & 25 \\
\hline & Shallow trench & 70 & Stone bund & 68 & Loss stone check dam & 37 \\
\hline & Stone bund & 81 & & & Percolation pond & 2 \\
\hline \multirow[t]{2}{*}{ Lelay wukro } & Hillside terrace & 95 & Deep trench & 75 & Half moon & 250 \\
\hline & Stone bund & 103 & Shallow trench & 56 & Gabion check dam & 9 \\
\hline \multirow[t]{3}{*}{ Tsigerda } & Hillside terrace & 125 & Half moon & 200 & Gabion check dam & 7 \\
\hline & Stone bund & 121 & Hillside terrace & 25 & Lose stone check dam & 2 \\
\hline & Shallow trench & 35 & Deep trench & 65 & Farm pond & 3 \\
\hline
\end{tabular}

Table 3 Mean and standard error $( \pm \mathrm{SE})$ compression of destroyed SWC structures (\%) on the upper slope of successfully and unsuccessfully performing watersheds

\begin{tabular}{llll}
\hline Name of Watershed & $\begin{array}{l}\text { Shallow trench } \\
\text { with stone bund }\end{array}$ & Hillside terrace & Stone bund \\
\hline Successful & $46.6(3.4)$ & $40.0(2.1)$ & $54.7(3.7)$ \\
Unsuccessful & $63.6(5.8)$ & $57.2(4.9)$ & $70.5(2.8)$ \\
$P$-value & 0.022 & 0.005 & 0.004 \\
\hline
\end{tabular}

Table 4 Mean and standard error $( \pm$ SE) compression of destroyed SWC structures (\%) on the middle slope of successfully and unsuccessfully performing watersheds

\begin{tabular}{llll}
\hline Name of watershed & Hillside terraces & Half-moon & Stone bund \\
\hline Successful & $47.1(5.6)$ & $38.7(3.4)$ & $51.6(3.3)$ \\
Unsuccessful & $61.4(4.0)$ & $57.7(4.4)$ & $65.9(3.4)$ \\
$P$-value & 0.05 & 0.003 & 0.008 \\
\hline
\end{tabular}

stone check dam, percolation pond was by 20.6 percent, 14.1 percent, and 6.4 percent higher on the unsuccessful watershed, respectively (Table 5).

\section{Major challenges of IWM practices}

The key challenges of the implemented IWM activities stated by the beneficiaries included lack of facilities (Gabion and cement), lack of maintenance, overgrazing and limited capacity to maintain the implemented measures (Table 6). More than 42 percent of the surveyed households in Deberewahabit and Gemad watersheds perceived lack of facility was the major challenge for poor success of the implemented measures. Moreover, more than $33 \%$ percent of the respondents in Adikesho indicated lack of maintenance as the major challenge. The major challenges stated for the unsuccessful Watersheds were overgrazing (26 percent for Debretsion), and Lack of facility (18.5 percent for Laelay Wukro and 21.3 percent for Tsigerda).
Table 5 Mean and standard error $( \pm \mathrm{SE})$ compression of destroyed SWC structures (\%) on the lower slope of successfully and unsuccessfully performance watersheds

\begin{tabular}{lllll}
\hline Name of Watershed & $\begin{array}{l}\text { Deep trench with } \\
\text { stone bund }\end{array}$ & Gabion check dam & $\begin{array}{l}\text { Loose stone } \\
\text { check dam }\end{array}$ & Percolation pond \\
\hline Successful & $36.5(4.4)$ & $32.5(3.0)$ & $57.8(3.1)$ & $51.6(11.3)$ \\
Unsuccessful & $57.1(2.6)$ & $80.3(6.0)$ & $71.9(5.8)$ & $58.0(10.1)$ \\
$P$-value & 0.001 & 0.000 & 0.05 & 0.674 \\
\hline
\end{tabular}


Table 6 Challenges of watershed management practices after IWM project phased out

\begin{tabular}{|c|c|c|c|c|c|c|}
\hline \multirow[t]{3}{*}{ Challenges } & \multicolumn{6}{|c|}{ Successful Watersheds } \\
\hline & \multicolumn{2}{|c|}{ Adikesho } & \multicolumn{2}{|c|}{ Debrwahbit } & \multicolumn{2}{|c|}{ Gemad } \\
\hline & Freq. & $\%$ & Freq. & $\%$ & Freq. & $\%$ \\
\hline Over grazing & 20 & 26.7 & 15 & 20 & 15 & 21.12 \\
\hline Lack of maintenance & 25 & 33.3 & 25 & 33.3 & 26 & 36.6 \\
\hline Lack of awareness & 10 & 13.3 & 5 & 6.7 & 0 & 0 \\
\hline Lack of facility & 20 & 26.7 & 30 & 40 & 30 & 42.25 \\
\hline Total & 75 & 100 & 75 & 100 & 71 & 100 \\
\hline \multirow[t]{3}{*}{ Challenges } & \multicolumn{6}{|c|}{ Unsuccessful watersheds } \\
\hline & \multicolumn{2}{|c|}{ Debretsion } & \multicolumn{2}{|c|}{ Laelay Wukro } & \multicolumn{2}{|c|}{ Tsigerda } \\
\hline & Freq. & $\%$ & Freq. & $\%$ & Freq. & $\%$ \\
\hline Over grazing & 20 & 26 & 7 & 12.9 & 15 & 20 \\
\hline Lack of awareness & 10 & 13 & 9 & 16.7 & 12 & 16 \\
\hline Lack of facility & 15 & 19.5 & 10 & 18.5 & 16 & 21.3 \\
\hline Less of biological conservation & 10 & 13 & 9 & 16.7 & 9 & 12 \\
\hline Lack of strong Keble ridership & 5 & 6.5 & 6 & 11.1 & 6 & 8 \\
\hline Total & 77 & 100 & 54 & 100 & 75 & 100 \\
\hline
\end{tabular}

Freq: frequency

\section{Discussion}

The major implemented IWM measures in the studied watersheds were shallow trench with stone bund, Hillside terrace, Stone bund, Half-moon, Deep trench with stone bund, Gabion check dam, Loose stone check dam and Percolation pond. Studies in Maego watershed, of northern Ethiopia (Dimtsu 2018) also reported such physical IWM measures implemented on the farmlands, closure areas and grazing land. These practices are also influenced by slope variation, in which, shallow trench with stone bund, hillside terrace and stone bund at the upper slope; hillside terraces, halfmoon, and stone bund at the middle slope; deep trench with stone bund, gabion check dam, loose stone check dam, and percolation pond at the lower slope. The number and the spacing between IWM structures in the watersheds depend on the slope gradient. Gessesse et al. (2009) and Dimtsu (2018) reported that when the spacing decrease slope gradient increases.

After IWM projects phased out, all IWM practices had shown a reduction in size and quality. The damage was pronounced in 40 percent (for hill side) to 70.5 percent (for stone bund) of the IWM practices on the upper slope. Furthermore, on the middle slope, damage between 38.7 percent (for half-moon) and 65.9 percent (for stone bund) was observed. It was also observed that IWM practices on the lower slope had shown a reduction after IWM project phased out ranging between 32.5 percent and 80.3 percent (for gabion check dam). This finding supports the study results of Nyssen et al. (2004) that reported about 40 percent destruction of check dams after two years of project phased out in Watersheds around Hagere Selam, northern Ethiopia.

The major reasons for the failure of the implemented IWM activities after IWM project phased out were lack of inputs, such as gabion and cement, lack of maintenance, overgrazing and limited capacity to maintain the implemented measures, as shown in Table 6. Similarly, Zeleke et al. (2006) estimated that 25 percent of the implemented stone bunds and 60 percent of the hillside terraces were destroyed due to lack of maintenance. Furthermore, Mekonen and Tesfahunegn (2011), for Medego watershed in northern Ethiopia, reported that lack of maintenance was one of the factors for soil and water conservation activities failure. In south-east Ethiopia Goba District Tiki et al. (2016) reported that 100 percent of the stone bunds are lost due to lack of maintenance and overgrazing. At the Wyebla Watershed, Northwest Ethiopia, 84.6 percent of the check dams was destroyed in which free grazing and lack of maintenance were the major drivers (Walie 2016). Limited technical and supply supports were also reported as drivers elsewhere (Alemu and Kidane 2014). The IWM implementation and phasing-out process was also characterized by lack of strong local institutions and poor community engagement. Lack of effective community engagement, poor technology implementation, insufficient policy, lack of stakeholder participation and lack of ownership strongly contribute to failure of IWM practices (Pretty and Ward 2001; Habtamu 2011; Meshesha and Birhanu 2015). 


\section{Conclusion}

The Integrated Watershed Management (IWM) practices implemented in the studied watersheds range from loose stone check dam to percolation pond. The type and quantity of these measures vary by variation in slope. After IWM projects phased out, all IWM practices, regardless of slope variation, had shown a reduction in size and quality. The major reasons for the failure of the implemented IWM activities after IWM project phased out were lack of inputs, such as gabion and cement, lack of maintenance, overgrazing and limited capacity, to maintain the implemented measures. It can be argued that integrated watershed management activities after IWM project phased out, regardless of the IWM class (successful and unsuccessful) are not sustainably kept. Hence, community engagement in all IWM processes is of paramount importance to sustainably manage the IWM practices.

Acknowledgements The authors express their gratitude to Mekelle University for the financial support.

Open Access This article is licensed under a Creative Commons Attribution 4.0 International License, which permits use, sharing, adaptation, distribution and reproduction in any medium or format, as long as you give appropriate credit to the original author(s) and the source, provide a link to the Creative Commons licence, and indicate if changes were made. The images or other third party material in this article are included in the article's Creative Commons licence, unless indicated otherwise in a credit line to the material. If material is not included in the article's Creative Commons licence and your intended use is not permitted by statutory regulation or exceeds the permitted use, you will need to obtain permission directly from the copyright holder. To view a copy of this licence, visit http://creativecommons.org/licenses/by/4.0/.

\section{References}

Alemu B, Kidane D (2014) The implication of integrated watershed management for rehabilitation of degraded lands: case study of Ethiopian highlands. J Agric Biodivers Res 3(6):78-90

Balasubramani K, Veena M, Kumaraswamy K, Saravanabavan V (2015) Estimation of soil erosion in a semi-arid watershed of Tamil Nadu (India) using revised universal soil loss equation (rusle) model through GIS. Model Earth Syst Environ 1(3):1-17

Bekele M (2003) Forest property rights, the role of the state, institutional exigency. Doctoral thesis in Uppsala, 409 (3): 227

Bekele S, Tilahun K (2007) Regulated deficit irrigation scheduling of onion in a semiarid region of Ethiopia. Agric Water Manag 89(1-2):148-152

Berry L (2003) Land degradation in Ethiopia: Its extent and impact. Commissioned by the GM with WB support, 2-7

BoARD (2016) Tigray Bureau of Agriculture and Rural Development (TBoARD) annual report. Mekelle, Ethiopia

Canadian Council of Ministers of the Environment [CCME] (2016). Summary of Integrated Watershed Management Approaches across Canada. Canadian Council of Ministers of the Environment. 27p. ISBN: 978-1-77202-034-2
Chisholm N, Woldehanna T (2012) Managing watersheds for resilient livelihoods in Ethiopia. Development Co-operation

Deressa TT, Hassan RM (2009) Economic impact of climate change on crop production in Ethiopia: evidence from cross-section measures. J African Econ 18(4):529-554. https://doi.org/10.1093/jae/ ejp002

Dimtsu G (2018) Technical evaluation of soil and water conservation measures in Maego Watershed, North Ethiopia. African J Environ Sci Technol 12(5):177-185

Etsay H, Negash T, Aregay M (2019) Factors that influence the implementation of sustainable land management practices by rural households in Tigrai region Ethiopia. Ecol Processes 8(1):14

FAO (1986) Highlands Reclamation Study, Ethiopia, Final Report, Vol. I, FAO, Rome. 354p

FAO (2006) Guidelines for soil description. Fourth edition. https:// scholar.google.com/scholar?hl=en\&as_sdt $=0 \% 2 \mathrm{C} 5 \& \mathrm{q}=\mathrm{FAO} \%$ 2C+\%282006\%29.+Guidelines+for+soil+description.+Fourth+ edition.\&btnG $=$ date $3 / 3 / 2020$

Gashaw T (2015) The implications of watershed management for reversing land degradation in Ethiopia. Res J Agric Environ Manag 4(1):5-12

Gessesse D, Gizaw AK, Hurni H (2009) Assessment of soil erosion and soil conservation practices in Angereb watershed, Ethiopia: technological and land user context. Biophysical and socio-economic frame conditions for the sustainable management of natural resources: Book of abstracts, 52

Habtamu T (2011) Assessment of sustainable watershed management approach case study lenche dima, tsegur eyesus and dijjil watershed. Master of professional studies thesis, Cornell University, Dahir Dar

Hurni H (1993) World Soil Erosion and Conservation: Land degradation, famine, and land resource scenarios in Ethiopia. Cambridge Univ Press, Cambridge, pp 27-62

Karpuzcu M, Delipinar Ş (2011) Integrated Watershed Management: Socioeconomic Perspective. Tojsat 1(3):1-7

Mekonen G, Fekadu A (2015) Experiences and challenges of integrated watershed management in central zones of southern Ethiopia. Int J Curr Res 7(10):20973-20979

Mekuria W, Veldkamp E, Haile M, Nyssen J, Muys B, Gebrehiwot K (2007) Effectiveness of exclosures to restore degraded soils as a result of overgrazing in Tigray Ethiopia. J Arid Environ 69(2):270-284

Meshesha YB, Birhanu BS (2015) Assessment of the effectiveness of watershed management intervention in Chena Woreda, Kaffa Zone, Southwestern Ethiopia. J Water Resour Prot 7(15):1257

MoARD (2005) Guideline for integrated watershed management. Addis Ababa, Ethiopia

MoARD (2007) Report on Irrigation Potential and Existing Irrigation Schemes by Region. Addis Ababa, Ethiopia

Nyssen J, Poesen J, Moeyersons J, Deckers J, Mitiku H, Lang A (2004) Human impact on the environment in the Ethiopian and Eritrean Highlands a state of art. Earth-Sci Rev 64:273-320

Nyssen J, Munro N, Haile M, Poesen J, Descheemaeker K, Haregeweyn N, Deckers J (2007) Understanding the environmental changes in Tigray: a photographic record over 30 years. Tigray Livelihood Papers 3:82

Nyssen J, Clymans W, Descheemaeker K, Poesen J, Vandecasteele I, Vanmaercke M, Moeyersons J (2010) Impact of soil and water conservation measures on catchment hydrological response-a case in north Ethiopia. Hydrol Process 24(13):1880-1895

Pretty J, Ward H (2001) Social capital and environment. World Dev 29(2):209-227

Rabia AH, Afifi RR, Gelaw AM, Bianchi S, Figueredo H, Huong TL, Solomon HW (2013) Soil mapping and classification: a case study in the Tigray Region, Ethiopia. J Agric Environ Int Develop 7:7-99 
Shiferaw B, Holden S (1999) Soil erosion and smallholders' conservation decisions in the highlands of Ethiopia. World Dev 27(4):739-752

Tamene L, Park SJ, Dikau R, Vlek PLG (2006) Reservoir siltation in the semi-arid highlands of northern Ethiopia: sediment yieldcatchment area relationship and a semi quantitative approach for predicting sediment yield Earth Surface Processes and Landforms. J British Geomorphol Res Group 31(11):1364-1383

Taye G, Poesen J, Wesemael BV, Vanmaercke M, Teka D, Deckers J, Haregeweyn N (2013) Effects of land use, slope gradient, and soil and water conservation structures on runoff and soil loss in semiarid Northern Ethiopia. Phys Geogr 34(3):236-259

Teka K (2019) What integrated watershed management can deliver for the environment and livelihoods: the Ethiopian Experience (Book chapter): In Elisabeth Simelton and Madelene Ostwarld (2019). Multifunctional Land Uses in Africa: Sustainable Food Security Solutions. Taylor and Francis. ISBN: 978-0-367-24644-0(hbk); ISBN: 978-0-429-28366-6(cbk)

Teka K, Van Rompaey A, Poesen J, Van Bruyssel S, Deckers J, Amare K (2014) Spatial analysis of land cover changes in Eastern Tigray (Ethiopia) from 1965 till 2007: are there signs of a forest transition? Land Degrad Dev 26:680-689. https://doi.org/10.1002/ldr. 2275

Tekle K (1999) Land degradation problems and their implications for food shortage in South Wello Ethiopia. Environ Manag 23(4):419-427

Temesgen H, Nyssen J, Zenebe A, Haregeweyn N, Kindu M, Lemenih M, Haile M (2013) Ecological succession and land use changes in a Lackretreat area (Main Ethiopian Rift Valley). J Arid Environ 91:53-60

Tiki L, Kewessa G, Wudneh A (2016) Effectiveness of watershed management interventions in Goba district, southeastern Ethiopia. Int J Agric Sci 6(9):1133-1140

Vancampenhout K, Nyssen J, Gebremichael D, Deckers J, Poesen J, Haile M, Moeyersons J (2006) Stone bunds for soil conservation in the northern Ethiopian highlands: Impacts on soil fertility and crop yield. Soil Tillage Res 90(1):1-15

Walie SD (2016) Evaluate the quality of physical soil and water conservation structures in Wyebla Watershed, Northwest Ethiopia. J Environ Earth Sci 6(3):2224-3216

Zeleke G (2014) Exit strategy and performance assessment for watershed management. A guideline for sustainability, WLRC -AAU, Addis Aeba, Ethiopia

Zeleke G, Kassie M, Pender J, Yesuf M (2006) Stakeholder analysis for sustainable land management (SLM) in Ethiopia: Assessment of opportunities, strategic constraints, information needs, and knowledge gaps. In Environmental Economics Policy Forum for Ethiopia (EEPFE), Addis Ababa, p 96

Publisher's Note Springer Nature remains neutral with regard to jurisdictional claims in published maps and institutional affiliations. 